\title{
On The Nature of Boredom
}

\author{
Can Sıkıntısının Doğası
}

\section{Pinar DURSUN*}

\begin{abstract}
Boredom is very common experience and has to date been accompanied by numerous negative psychological, social, academic, occupational and interpersonal problems. Boredom which is a highly complex and multidimensional concept has been conceptualized differently within different paradigms throughout the ages. However, in modern psychology literature, some theorists define it as the opposite feeling to interest and an aversive negative feeling derived from low arousal or from monotonous situational factors (Mikulas \&Vodanovich 1993); while some theorists define it as a personality trait or a disposition- proneness to boredom- which refers to the fact that some individuals tend to experience greater boredom than others (Farmer \& Sundberg 1986; Vodanovich, Verner, \& Gilbride 1991). There are also cognitive, behavioral and psychophysiological components of boredom and recently some individual or personality factors have been found to be associated with boredom. Boredom could also influence the quality of rapport in the psychotherapeutic process and could lead to early termination if it has not been seriously treated. The aim of this paper is to provide a general review of the components and correlates of boredom on the basis of recent studies.
\end{abstract}

Keywords: Boredom, Proneness to Boredom, Correlates of Boredom, Boredom in Psychotherapy

$\ddot{O}_{z}$ : Can sıkıntısı oldukça yaygın bir deneyimdir ve şimdiye kadar pek çok psikolojik, sosyal, akademik, çalışma hayatı ve kişilerarası problemlerle ilişkilendirilmektedir. Can sıkıntısı, oldukça karmaşık ve çok boyutlu bir kavram olup tarih boyunca, farklı paradigmalarda farklı türde kavramsallaştııılmıştır. Ancak modern psikoloji literatüründe, bazı kuramcılar, can sıkıntısını, ilgi duymanın tersi ve düşük uyarılma ya da monoton durumların sonucu olarak hissedilen olumsuz bir duygulanım olarak tanımlarken (Mikulas \& Vodanovich 1993), bazı kuramcılar bir tür kişilik ya da bireysel bir özellik/treyt ya da dizpozisyon olarak tariflemektedir (Farmer \& Sundberg 1986; Vodanovich et al.1991). Aynı zamanda, bilişsel, davranışsal ve psikofizyolojik bileşenler ile son zamanlarda bazı kişilik özellikleri, can sıkıntısı ile ilişkili bulunmuştur. Can sıkıntısı, psikoterapötik süreç içerisinde ilişkinin kalitesini etkileyebilir ve uygun ele alınmazsa erken bırakılmalara yol açabilir. Bu çalışmadaki amaç, yakın zamanlardaki çalışmaları da göz önünde bulundurarak, can sıkıntısının bileşenleri ve ilgili değişkenleri gözden geçirmektir.

Anahtar kelimeler: Can Sıkıntısı, Can Sıkıntısı Yatkınlı̆̆ı, Can Sıkıntısı Değişkenleri, Psikoterapide Can Sikıntıs1

Some individuals are more prone to engage in repeated experiences, such as watching the same movie, visiting the same places time after time, eating same kinds of food; while some individuals are eager to experience new things such as listening to new music, tasting new foods, travelling new places and meeting new people. In the latter case, these individuals easily become bored by repeated experiences. However, more or less, everybody experiences

\footnotetext{
*Yrd. Doç. Dr., Afyon Kocatepe Üniversitesi, Fen-Edebiyat Fakültesi, Psikoloji Bölümü, Afyon. pdursun@aku.edu.tr
} 
boredom. It occurs in various circumstances, sometimes while reading a paper, listening to a lecture, sometimes while doing household chores, and while having a relationship.

Boredom which has to date been associated with significant psychological, behavioral and social difficulties is one of the most common emotional states. People often react with contempt to complaints of boredom, as indeed, life is full of interesting things. Nevertheless boredom is very prevalent. According to Klapp (1986), from $18 \%$ to $50 \%$ of population were bored from 1960 's to the 1980's (cited in Eastwood et al. 2007) and recently 91\% of U.S. youth reported they experience boredom (National Center on Addiction and Substance Abuse 2003 cited in Eastwood, Frishen, Fenske \& Smilek 2012).

In educational, health, clinical, organizational, and social settings, studies on boredom constitute an impressive body of research. These have associated boredom with numerous negative outcomes such as psychological symptoms-depression, anxiety, obsessions, somatization, and interpersonal sensitivity (Sommers \& Vodanovich 2000), paranoia and heightened private self-consciousness and negative self-awareness (von Gemmingen, Sullivan \& Pomerantz 2003), negative personality traits (Vodanovich et al. 1991), juvenile delinquency (Newberry \& Duncan 2001), drug use (Anshel 1991; Iso-Ahola \& Crowley 1991), sensation seeking, aggression, unsafe driving behavior and impulsiveness (Dahlen, Martin, Ragan, \& Kuhlman 2004, 2005), procrastination (Blunt \& Pychyl 1998; Vodanovich \& Rupp 1999), decreased academic achievement (Mann \& Robinson 2009), truancy, drop out and job dissatisfaction (Eastwood et al. 2007) and relational dissatisfaction (Harasymchuk \& Fehr 2010), loneliness, depression and general dissatisfaction with life (Farmer \& Sundberg 1986) and even death (Britton \& Shipley 2010). For instance, in an academic environment feeling bored negatively influences motivation, cognitive resources, the learning process and achievement outcomes (Preckel, Götz \& Frenzel 2010). Also, student boredom has been linked to decreased academic achievement and school dissatisfaction which mostly leads to maladaptive behaviors (Mann \& Robinson 2009). Boredom prone individuals are more likely on vigilance tests to experience cognitive failures (Sawin \& Scerbo 1995) and are dissatified with their jobs (Kass et al. 2001). They also experience greater relational boredom in their romantic life (Harasymchuk \& Fehr 2010). Additionally, proneness to boredom has been found to be a risk factor for cognitive impairment in old age and is associated with less cognitive reserves independent of the age and education level of individuals (Conroy, Golden, Jeffares, O’Neil \& McGee 2010).

\section{What is boredom?}

In general, boredom is described as "unpleasant, transient affective state, in which the individual feels a pervasive lack of interest" (Fisher 1993, 396). Mikulas and Vodanovich $(1993,3)$ defined boredom as "a state of relatively low arousal and dissatisfaction, which is attributed to an inadequately stimulating situation". Even though it has been mostly defined as a transitional or momentary state (e.g. resulting from repetition or from lack of arousal or novelty), some authors suggested that boredom could have a trait-like aspect - boredom susceptibility (Zuckerman 1979) and boredom proneness (Farmer \& Sundberg 1986; Vodanovich et al. 1991; Vodanovich 2003). Some authors have suggested the lack of intrinsic meaning (e.g. a lack of meaning in enrolled activity) or a loss of "flow"- the loss of a feeling of wholeness and full involvement- lead to feeling of boredom (Csikszentmihalyi 1975, 1990).

In the last few decades, most researchers have attempted to examine the reasons for boredom. Yet, very little known about its nature. The main consensus is that boredom is a complex, multidimensional and comprehensive phenomenon (Martin, Sadlo \& Stew 2006). 
Since the definitions of boredom are somewhat conflicting and multifaceted, in this paper, our aim is to provide a brief review of possible components and correlates of boredom. However prior to this, it seems worthwhile to mention some historical record concerning the roots of boredom.

\section{Roots of boredom}

Throughout the ages, philosophers, novelists and poets have recorded ideas concerning the subjective experience of boredom. The ancient Greek philosophers used the word "acedia" for its description. Socrates was harshly criticised for being monotonous and repetitive in his writings (Martin et al. 2006). However, Plato defended the need for consistency and regularity of the heavenly bodies, similar to Christians such as St. Thomas Aquinas. With the advent of Christianity, "acedia" was understood to be one of the "seven deadly sins" (Mansikka 2009). Several words were used to represent the concept of boredom, such as "dryness of the soul", "inexplicable sorrow", "loss of love", "complete paralysis of the will". It was represented as a form of spiritual disorder. Because when individuals are full of joy, they also immune to all other sins, when people suffer from boredom, they will inevitably seek some instant and immediate pleasure which itself represents self deception and distance from the love of God. It was assumed to be a kind of distortion of the relationship to God (Mansikka 2009). The English word "boredom" first appeared in print in 1766. The French term for boredom, "ennui" is also sometimes employed in English as well and many philosophers and authors such as Durkheim, Baudelaire, Dostoevsky, Nietzsche, Flaubert and Kierkagaard were attached to this newly coined concept, while the artist Walter Richard Sickert completed a series of drawings, an oil painting and engravings entitled Ennui 1913-1914. The existentialists such as Camus and Sartre defined boredom as a "indifference to the life", "meaninglessness" or "inside emptiness", and they believed that without stimulus, the individual is confronted with nothingness, the meaninglessness of existence, and so the individual in consequence experiences existential anxiety (Martin et al. 2006). Modern literature relating to boredom does not regard it as a moral or existential reaction. The human being today feels isolated and tends to strive to achieve a fully functioning capacity or self-realization (Mansikka 2009). Today, boredom is considered a a complex phenomenon that includes psychological, social, and physiological dimensions.

\section{Components of boredom}

\section{Affective components of boredom}

Is boredom only an emotional state? Most research has defined boredom as being the opposite emotion to interest. If boredom were only an emotion, then, all processes to identify emotions should be valid for boredom as well, such as facial expression, autonomic arousal, posture and situational information (Damrad-Frye \& Laird 1989). On the contrary, boredom unlike other emotions such as happiness, anger or disgust does not produce overt actions. It seems far more complicated than basic emotions but still is related to negative affects.

Boredom has been accompanied by a constellation of negative emotions such as sadness, depressive feelings, emptiness, hopelessness, meaninglessness, lethargy, feeling trapped, restlessness, frustration, anxiety, worry, anger (von Gemmingen et al. 2003; Culp 2006; Martin et al. 2006). Hill and Perkins (1985) suggested that boredom is an affective experience which is associated with the cognitive-attentional processes. Subjectively monotonous activities could lead to a high degree of frustration and boredom whereas disliked activities could lead to a low degree of frustration. Based upon the experience of the level of frustration, people may feel aggressive, worried or hostile. In order to cope with these aversive feelings, people could find 
alternative ways or stimulating processes to handle the onset of boredom and emotional distress (Kelly 2002).

In short, boredom is a complex phenomenon and entails both low arousal emotions such as sadness, depression, and feeling fatigue, as well as high arousal emotions such as frustration, agitation, anxiety and restlessness (Harasymchuk \& Fehr 2010).

The classical psychoanalytic approach explains boredom as a complex phenomenon resulting from inner dynamics and conflicts, especially through providing a link between boredom, anger and aggression (Dahlen, Martin, Ragan, \& Kuhlman 2004). Fenichel (1951) describes boredom as "internalized anger", "inner anger" or, "a concealed form of aggression" (cited in Rupp \& Vodanovich 1997). If an individual is not allowed to show anger, boredom could represent the feeling of anger. Additionally, boredom is a sense of emptiness, a distorted sense of time, a passive, anticipative attitude from the dissapointed hope that the external World would provide and satisfy the need for stimulation. According to Fenichel (1953) boredom arises not only when there is a conflict between psychic dynamics, but also when an individual does not know how to be active (cited in Eastwood et al. 2007, 2012). In fact, a bored individual does not lack something to do, rather s/he is unable to designate the type of activity required to satisfy the supposed need for stimulation. The ideational content of an instinctual aim, such as a fantasy life full with aggression or sexuality, is out of awareness and lies down in the unconscious level, nevertheless, its accompanying emotion, boredom, is at the level of awareness and consciousness. Thus, the person wishes s/he had something to do but does not know how to do it or to label or to recognize what exactly would satisfy his/her needs for fulfillment (Dahlen et al. 2004; Eastwood et al. 2007). In other words, boredom is a conflict between mental engagement and being unable to engage with it. Similarly, Fenichel (1951) states that "boredom occurs when we must not do what we want to do, or must do what we do not want to do" (cited in Damrad-Frye \& Laird 1989). It could also be a consequence of the feeling of coercion. When one is compelled to do something or when one is inhibited from doing what $\mathrm{s} /$ he wants, then $\mathrm{s} / \mathrm{he}$ is more likely to feel bored.

\section{Psychophysiological components of boredom}

Boredom has been accompanied by various physiological changes. Merrifield and Danckert (2014) investigated the psychophysiological structure of boredom amongst undergraduate students by inducing boredom, interest, sadness, and neutral affective states through measuring their heart rate, skin conductance levels, and cortisol levels. As a result of this study it was found that the physiological reactions from boredom differ from other emotional states in terms of an increased heart rate and cortisol levels and a decreased skin conductance level compared to sadness, interest or to neutral states. It is suggested that boredom is related to increased arousal (heart rate and cortisol level) and decreased vigilance or attentional level, as being very similar to the autonomous nervous system pattern of Attention-Deficit Hyperactivity Disorder (ADHD; Hermens et al. 2004). In this respect, further studies can include the relationship between ADHD and proneness to boredom.

Jiang et al. (2009) examined the relationships between boredom susceptibility, sensation seeking and psychophysiological changes through ERP- event related potential techniques through exposing the participants to new stimuli and repeated stimuli. The authors have shown that participants in extreme sports and skydivers have greater large frontal LPC-late positive correlates- amplitude than the control groups. When participants are exposed to a novel stimuli, the positive brain potentials appear more in sensation seekers and sensation seekers habituate 
more rapidly to the stimuli than do the others. Nevertheless, the neural roots of this rapid habituation and amplitude differences remain still the subject of debate.

\section{Cognitive Components of Boredom}

Watt and Vodanovich (1999) describe boredom as a dislike of repetition or of routine and is particularly evident when the environment is lacking in novelty and stimulation. Specifically it is a condition that is characterized by the perception of one's environment as dull, banal, monotonous and lacking in stimulation (Eastwood et al. 2007; Harasymchuk \& Fehr 2010). It is for the individual a kind of death of meaning in this situation. This may result from leisure and a lack of aesthetic or any personal interests. Some individuals may perceive or interpret the same environmental cues as being less interesting and less arousing (Mikulas \& Vodanovich 1993; Barnett \& Klitzing 2006). Cognitive theorists explain the antecedents of affect, as being both negative and positive in terms of the interpretational/appraisal system of an individual. Appraisal can be defined as the kind of personal meaning of an event, which includes the evaluations of the significance of the facts for personal well-being (Leon \& Hernandez 1998; Mann \& Robinson 2009). Two persons encounter two different physical conditions and on the basis of their personal constructs and appraisal systems, mainly feel differently (Hill \& Perkins 1985). Thus individuals prone to high boredom may interpret the environment as being less arousing, more monotonous, and less interesting. In other words, if the stimulus means nothing for the individual or is perceived as being banal and or less distinct, it gives rise to the state of boredom.

In addition to perceptions of the outer world, the experience of boredom can be explained by the perception of the dilatation of time and of attention. Bored individuals complain about the slowness of time, they frequently report that "time stands still" or that "time seems endless, no distinction among past, present and future" (Vodanovich \& Watt 1999; Preckel et al. 2010). They try to erase the time in order to deal with the perception of slowness, since the feeling of boredom leads to the heightened awareness in the passing of time. Consistently, high boredom prone individuals tend to perceive time as passing more slowly than low boredom prone individuals (Blunt \& Pychyl 1998). Similarly, Danckert and Allman (2005) have found in their studies that high boredom prone individuals demonstrated higher errors in estimating the passage of time. This highlights the subjective perception of time in reading passages. In accordance with this finding, Watt (1991) found that when compared to low boredom prone people, high boredom prone people rated a boring task -circling numbers- as taking more time to complete (cited in Danckert \& Allman 2005). Thus, if an individual feels an activity takes longer than it actually does, this relative interpretation may lead to an elevated experience of boredom. In other words, time flies when you have fun, because you forget the time and boredom dissolves. High boredom individuals think that they have been performing a task for longer than it actually takes. Thus they feel more impatient with the task and experience greater boredom. Conversely, the reason why "time flies when we have fun" is perhaps that this perception allows us to keep performing the task through motivation and to maintain greater attention and concentration levels for longer periods, which permits us to complete the task more properly with less errors and which results in the enjoyment of the task itself (Danckert \& Allman 2005). Nevertheless, the subjective or relative perception of boredom also depends upon the cognitive workload for the individual, especially when you have less motivation to complete your tasks (Conti 2001). Thus the tendency to overestimate the passage of time among high boredom prone individuals may be partly related to the perceived effort required to perform a given task. Danckert and Allman (2005) state that high boredom people tend to rate their 
performance as more effortful than low boredom prone individuals do. Similarly, Leary, Rogers, Canfield, and Coe (1986) found that when a task requires a great deal of time and effort, to continue giving attention to a stimulus that is not intrinsically motivating, the affective response to this effortful concentration and the energy for vigilance is called "boredom" (cited in Harris 2000). However, boredom does not only result from overchallenging conditions and increased attention effort conditions. Boredom is also due to a lack of challenge or to underchallenging situations. In line with this study, Preckel et al. (2010) suggest that students with high cognitive abilities may see academic tasks as being not very challenging which results in the more frequent feeling of boredom. Although having a high cognitive workload especially high level of vigilance requirement and being coerced to do a task can be very important causes for the feeling of boredom. Concerning this issue, a few studies with gifted and non-gifted children indicate inconsistent findings (see Martin et al. 2006). In sum, boredom is usually defined as the aversive state caused by inappropriate levels of challenge, both overchallenging (problems with understanding) and underchallenging (already knowing the content well) conditions (Mikulas \& Vodanovich 1993; Preckel et al. 2010). Therefore, there should be an optimal flow or a balance between the environmental challenges and skills of the individual for the absence of boredom. Skills should be perceived as being greater than the challenges to motivate individuals.

Incongruent with the slowness of time perception for bored individuals, London and Monell (1974) carried out a study related to self-perception analysis which refers to labeling feelings based upon observing and interpreting others' feelings and behaviors, in addition to the context in which boredom appears (cited in Damrad-Frye \& Laird 1989). In this study, two experimental groups were asked to perform a 20 -min task. One group's clock was manipulated to accelerate the time which means that although 20 minutes have passed after they began to perform their tasks the participants believed that only 10 minutes had passed. On the contrary, the other group's clock was manipulated to show that 30 minutes had passed instead of 20 minutes. The two groups completed the task and were asked whether task was boring or not. The first group rated task was more boring than the second group. Because their clock was altered, the first group felt that they had worked for a longer time, then the task must be boring. The second group conversely felt that they performed their tasks in much less time, it had seemed much less, so the task must be interesting. The authors interpreted this result to show that boredom could be related to the metacognition about the task itself rather than actual time the task took.

On the other hand, Eastwood et al. (2007) examined the association between boredom and attention and concentration level. They suggest that the misallocation or the unequal distribution of attention toward stimuli, such as subtle distraction, can lead to the feeling of boredom. For instance, Damrad-Frye and Laird (1989) indicate that when participants are distracted by noise, but do not recognize the role of noise or the source of distraction, they tend to report greater boredom and do not enjoy the task or find it interesting. Also there are couple of studies regarding sustained attention -executive network of attention- and boredom which mostly showed that if the assigned task requires a long time to be completed and much vigilance, such as monitoring a signal detection continuously, participants experience higher levels of boredom and in monitoring perform less well (e.g. Pattyn, Neyt, Henderickx \& Soetens 2008; Malkovsky, Merrifield, Goldberg \& Danckert 2012).

\section{The behavioral components of boredom}

Boredom is mostly caused through a perceived inadequately stimulating situation, such as a lack of novelty, a lack of arousal, some lack of intrinsic meaning. Even though Frijda (1986) 
described boredom as a deactivation state related to the absence of behavior, and puzzled with the antecedents as to why some stimuli led to a decrease in activation below the normal, some theorists state that boredom has an adaptive purpose in alerting people to take action (e.g., Harasymchuk \& Fehr 2010). Boredom itself can be a motivational concept to cope with the antecedents of boredom. A few theorists have hypothesized that boredom may occasionally lead to positive outcomes such as increasing creativity and in motivating change (e.g. Harris 2000; Mansikka 2009). Heidegger (1995) argued that experiencing profound boredom as a part of feeling existential indifference, rather than situational boredom, can become transformative or result in a radical turn for "being" (dasein) and may enhance the original possibilities to avoid this emptiness. On the other hand, engaging in tasks that requires lower productivity is accompanied with higher level of boredom. For instance, it was found that bored workers have a lower probability of completing projects than non-bored workers and bored students are more likely to avoid school work than non-bored students (Culp 2006). Perhaps in order to cope with the feeling of boredom, people may engage in certain maladaptive coping strategies such as over-eating, unsafe driving, gambling, substance use/abuse, sensation seeking behaviors, impulsive activities, procrastination (Harris 2000; Culp 2006).

\section{Personality and boredom}

Personality is a broad concept, constructed through heritage, environmental factors, experiences and modeling (Garcia 2011). Generally, proneness to boredom has been associated with several negative personality traits and negative emotional states, such as sadness, lethargy, displeasure, distress, anger, guilt, emptiness (Barnett \& Klitzing 2006; Culp 2006). Barnett and Klitzing (2006) have found that boredom prone individuals have higher levels of negative affect in their daily lives.

Research concerning the relationship between personality dimensions and the experience of boredom suggests that narcissism could be one of the key characteristics in explaining boredom. Narcissism has been found to be correlated with boredom, especially covert narcissism, which is characterized by the minimal motivation to excel, and which is related to depressive thoughts and feeling of inferiority that masks grandiosity (von Gemmingen et al. 2003). Wink and Donahue (1997) claim that boredom is a mismatch one's inner ambitions (ideal self) and one's current goals (actual self). This leading to dissatisfaction. These authors also found that covertly narcissistic individuals have an underlying inflated sense of self, depressive thoughts and feelings as well as proneness to boredom. They also suggested that individuals prone to boredom are more likely to have self-centered views. As they expected, these authors have found a positive relationship between narcissism and boredom. Covert narcissism is associated with the perception of time as passing slowly, such persons are inner directed and self centered (Wink \& Donahue 1997).

The "Big Five" personality dimensions are, Extraversion (activity and dominance in social situations), Agreeableness (ability to maintain positive and reciprocal relationships with others), Conscientiousness (planful, organized, and responsible behavioral tendencies), Emotional Stability or Neuroticism (ability to regulate negative emotions), and Openness (curiosity to new experience and creativity) (McCrae \& John 1992). Regarding these big five personality traits, several studies have shown that individuals with neuroticism are more likely to experience boredom (Barnett \& Klitzing 2006; Culp 2006; Dahlen \& White 2006). Neurotic individuals are found to be more anxious, depressed and less social with others, similar to individuals prone to boredom, who may have a difficulty in regulating their emotions. In terms of extraversion, Culp (2006) suggests that there was no significant correlation between extraversion and proneness to 
boredom, whereas Barnett and Klitzing (2006) have found that extraversion has been negatively correlated with leisure boredom. More specifically, introverted students are more likely to experience boredom mostly due to their social isolation. Also, none of the studies have found any significant relationship between openness to experience and proneness to boredom. Lastly, a negative relationship has been found between conscientiousness and boredom (Culp 2006). This may be related to the argument that conscientious individuals are more responsible, hard working, disciplined and consistent, as they tend to set higher goals in their lives and are motivated to make them real (Komarraju, Karau \& Schmeck 2009); whereas individuals prone to boredom are more likely to avoid performing tasks, procrastinate more and also experience fear of failure.

\section{Boredom in psychoterapeutic settings}

In health settings, the patients or clients may exhibit higher level of boredom and this may influence the commitment and motivation levels of both client and psychotherapist toward the sessions. Taylor (1984) suggested that unless technical modifications are employed, some clients are more likely to feel boredom and sessions more quickly reach an impasse and in consequence, early terminations can easily occur. In particular, unmotivated clients -sent by a judge or a spouse or a parent, may be defensive, or uncommitted or bored (Morrant 1984). Bored clients can evoke boredom in the therapists as well. The therapist may feel frustration and anger, s/he may engage in lots of questioning, confronting and inappropriate interpreting. Boredom in therapy can simply be the result of the client's resistance, or it can be experienced when superficial talk occur and the discussion of facts are avoided (Morrant 1984). Perhaps boredom is a protection against one's own feelings of anger and/or guilt towards a psychotherapist (Taylor 1984; Morrant 1984). Sometimes boredom is defined as a consequence of both transference and countertransference. That is to say, boredom could be experienced by both the therapist and the client. This may lead to an impasse in sessions which results in their premature termination or loss of meaning in the helping process or to the use of inappropriate or the overuse of techniques in the attempt to decrease the negative feeling of boredom. Therefore the experience of boredom should be detected as early as it happens, so the structure of the sessions could be rearranged.

\section{Conclusion}

Even though boredom is common experience for everyone, it remains a complex and multidimensional phemonenon to understand completely. To date various research has shown that the experience of boredom is associated with a range of psychological, social, academic, occupational and relational difficulties. In brief, it has been defined as being both a momentary state of an affective response (Fisher 1993) and a personality trait, proneness to boredom (Mikulas \& Vodanovich 1993). However, the occurence of boredom has been related to many different factors, namely, affective -(conflict between mental engagement and unfulling desires), cognitive (subjective interpretation of what is boring and level of attention), behavioral (arousal levels of an environment) and psychophysiological (bodily responses and sensation seeking) components. Some theorists (e.g., Barnett \& Klitzing 2006) suggest that boredom is also correlated with some personality traits, mainly with neuroticism and covert narcisisism. In terms of the implications of the experience of boredom: it may be a threat to the quality of the therapeutic relationship and disrupt the rapport between therapist and client, and it may also lead to immature termination, or, to evoke impasse or resistant feelings on one, or both sides; which may damage the relationship. Therefore the experience of boredom has to be considered 
as a factor of negative influence in such relations and, when this occurs, it must be realized and treated properly within the therapeutic setting. In conclusion, the aim of this paper was to briefly review the correlates and components of boredom, in order to alert the reader, to make them more aware and to pay more attention to this frequent and disruptive experience. It can surely be noted that future studies can address the measurement of boredom, with its true conceptualization such as clarifiying state or trait boredom difference, and empirically through examining boredom in different settings with various examples. 


\section{REFERENCES}

Anshel M. H. (1991). "A Survey of Elite Athletes on the Perceived Causes of Using Banned Drugs in Sport". Journal of Sport Behavior 14 (1991) 283-310.

Barnett L. A. \& Klitzing S. W. (2006). "Boredom in Free Time: Relationships with Personality, Affect, and Motivation for Different Gender, Racial, and Ethnic Students Groups". Leisure Sciences 28 (2006) 223-244.

Blunt A. \& Pychyl A. (1998). "Volitional Action and Inaction in the Lives of Undergraduate Students: Statorientation, Procrastinationa and Proneness to Boredom". Personality and Individual Differences 24/6 (1998) 837-846. Doi: 10.1016/S0191-8869(98)00018-X.

Britton A. \& Shipley M. J. (2010). “Bored to Death?”. International Journal of Epidemiology 39/2 (2010) 370-371.

Conroy R. M., Golden J., Jeffares I., O’Neil D. \& McGee H. (2010). "Boredom-Proneness, Loneliness, Social Engagement and Depression and Their Association with Cognitive Function in Older People: A Population Study". Psychology, Health \& Medicine 15/4 (2010) 463-473.

Conti R. (2001). "Time Flies: Investigating the Connection Between Intrinsic Motivation and the Experience of Time". Journal of Personality 69/1 (2001) 1-26.

Csikszentmihalyi M. (1975). "Play and Intrinsic Rewards". Journal of Humanistic Psychology 15 (1975) 41-63.

Csikszentmihalyi M. (1990). Flow: The Psychology of Optimal Performance. New York 1990.

Culp N. A. (2006). "The Relations of Two Facets of Boredom Proneness with the Major Dimensions of Personality". Personality and Individual Differences 41 (2006) 999-1007.

Dahlen E. R., Martin R. C., Ragan K. \& Kuhlman M. M. (2004). "Boredom Proneness in Anger and Aggression: Effects of İmpulsiveness and Sensation Seeking”. Personality and Individual Differences 37/8 (2004) 1615-1627.

Dahlen E. R., Martin R. C., Ragan K. \& Kuhlman M. M. (2005). "Driving Anger, Sensation Seeking, Impulsiveness, and Boredom Proneness in the Prediction of Unsafe Driving". Accident Analysis \& Prevention 37/2 (2005) 341-348.

Dahlen E. R. \& White R. P. (2006). "The Big Five Factors, Sensation Seeking, and Driving Anger in the Prediction of Unsafe Driving". Personality and Individual Differences 41/5 (2006) 903-915.

Damrad-Fyre R. \& Laird J. D. (1989). "The Experience of Boredom: The Role of the Self Perception of Attention". Journal of Personality and Social Psychology 57/2 (1989) 315-320.

Danckert J. A. \& Allman A. A. A. (2005). "Time Flies When You're Having Fun: Temporal Estimation and the Experience of Boredom". Brain and Cognition 59 (2005) 236-245.

Eastwood J. D., Frischen A., Fenske M. J. \& Smilek D. (2012). "The Unengaged Mind Defining Boredom in Terms of Attention". Perspectives on Psychological Science 7/5 (2012) 482-495.

Eastwood J. D., Cavaliere C., Fahlman S. A., \& Eastwood A. E. (2007) "A Desire for Desires: Boredom and its Relation to Alexithymia". Personality and Individual Differences 42 (2007) 1035-1045.

Farmer R. \& Sundberg N. D. (1986). "Boredom Proneness the Development and Correlates of a New Scale". Journal of Personality Assessment 50 (1986) 4-17.

Fisher C. D. (1993). "Boredom at Work: A Neglected Concept". Human Relations 46/3 (1993) 395- 417.

Frijda N. H. (1986). The Emotions. Cambridge 1986.

Garcia D. (2011). "Two Models of Personality and Well-Being Among Adolescents". Personality and Individual Differences 50/8 (2011) 1208-1212.

Harasymchuk C. \& Fehr B. (2010). "A Script Analysis of Relational Boredom: Causes, Feelings, and Coping Strategies". Journal of Social and Clinical Psychology 29/9 (2010) 988-1019.

Harris M. B. (2000). "Correlates and Characteristics of Boredom Proneness and Boredom". Journal of Applied Social Psychology 30 (2000) 576-598.

Heidegger M. (1995). The Fundamental Concept of Metaphysics: World, Finitude, Solitude. Bloomington 1995. 
Hermens D. F., Williams L. M., Lazzaro I., Whitmont S., Melkonian D. \& Gordo, E. (2004). "Sex Differences in Adult ADHD: a Double Dissociation in Brain Activity and Autonomic Arousal". Biological Psychology 66/3 (2004) 221-233.

Hill A. B., \& Perkins R. E. (1985). “Towards a Model of Boredom”. British Journal of Psychology 76 (1985) 235-240.

Iso-Ahola S. E. \& Crowley E. D. (1991). “Adolescent Substance Abuse and Leisure Boredom”. Journal of Leisure Research 23/3 (1991) 260-271.

Jiang Y., Lianekhammy J., Lawson A., Guo C., Lynam D., Joseph J. E., Gold B. T. \& Kelly T. H. (2009). "Brain Responses to Repeated Visual Experience Among Low and High Sensation Seekers: Role of Boredom Susceptibility". Psychiatry Research: Neuroimaging 173/2 (2009) 100-106.

Kass S. J., Vodanovich S. J. \& Callender A. (2001). "State-Trait Boredom: Relationship to Absenteeism, Tenure, and Job Satisfaction”. Journal of Business and Psychology 16/2 (2001) 317-327.

Kelly W. E. (2002). "Some Evidences for Nonpathological and Pathological Worry as Separate Constructs: an Investigation of Worry and Boredom". Personality and Individual Differences 33 (2002) 345-354.

Komarraju M., Karau S. J. \& Schmeck R. R. (2009). "Role of the Big Five Personality Traits in Predicting College Students' Academic Motivation and Achievement”. Learning and Individual Differences 19/1 (2009) 47-52.

Leon I., \& Hernandez J. A. (1998). "Testing the Role of Attribution and Appraisal in Predicting Own and Other's Emotions". Cognition and Emotion 12/1 (1998) 27-43.

Malkovsky E., Merrifield C., Goldberg Y. \& Danckert J. (2012). "Exploring the Relationship Between Boredom and Sustained Attention”. Experimental Brain Research 221/1 (2012) 59-67.

Mann S. \& Robinson A. (2009). "Boredom in the Lecture Theatre: An Investigation into the Contributors, Moderators, and Outcomes of Boredom Amongst University Students". British Educational Research Journal 35/2 (2009) 243-258.

Mansikka J. E. (2009). “Can Boredom Educate Us? Tracing a Mood in Heidegger's Fundamental Ontology from an Educational Point of View". Studies in Philosophy and Education 28/3 (2009) 255-268.

Martin M., Sadlo, G. \& Stew G. (2006). "The Phenomenon of Boredom". Qualitative Research in Psychology 3/3 (2006) 193-211.

McCrae R. R. \& John O. (1992). "An Introduction to the Five-Factor Model and its Applications". Journal of Personality 60 (1992) 175-215.

Merrifield C. \& Danckert J. (2014). "Characterizing the Psychophysiological Signature of Boredom". Experimental Brain Research 232/2 (2014) 481-491.

Mikulas W. L. \& Vodanovich S. J. (1993). "The Essence of Boredom". The Psychological Record 43 (1993) 3-12.

Morrant J. C. (1984). "Boredom in Psychiatric Practice". The Canadian Journal of Psychiatry/La Revue canadienne de psychiatrie 29/5 (1984) 431-434.

Newberry A. L. \& Duncan R. D. (2001). "Roles of Boredom and Life Goals in Juvenile Delinquency". Journal of Applied Social Psychology 31/3 (2001) 527-541.

Pattyn N., Neyt X., Henderickx D. \& Soetens E. (2008). "Psychophysiological Investigation of Vigilance Decrement: Boredom or Cognitive Fatigue?". Physiology \& Behavior 93/1 (2008) 369-378.

Preckel F., Götz, T. \& Frenzel A. (2010). “Abiltity Grouping of Gifted Students: Effects on Academic Self- Concept and Boredom”. British Journal of Educational Psychology 80 (2010) 451-472.

Rupp D. E. \& Vodanovich S. J. (1997). "The Role of Boredom Proneness in Self-Reported Anger and Aggression”. Journal of Social Behavior and Personality 12/4 (1997) 925-936.

Sawin D. A. \& Scerbo M. W. (1995). "Effects of Instruction Type and Boredom Proneness in Vigilance: Implications for Boredom and Workload”. Human Factors 37 (1995) 752-765.

Sommers, J., \& Vodanovich, S. J. (2000). "Boredom Proneness: Its Relationship to Psychological-and Physical-Health Symptoms". Journal of Clinical Psychology 56/1 (2000) 149-155.

Taylor G. J. (1984). "Psychotherapy with the Boring Patient". The Canadian Journal of Psychiatry/La 
Revue canadienne de psychiatrie 29/3 (1984) 217-222.

Von Gemmingen M. J., Sullivan B. F. \& Pomerantz A. M. (2003). "Investigating the Relationship Between Boredom Proneness, Paranoia, and Self-Consciousness". Personality and Individual Differences 34 (2003) 907-919.

Vodanovich S. J. (2003). "Psychometric Measures of Boredom: A Review of the Literature". The Journal of Psychology 137/6 (2003) 569-595.

Vodanovich S. J. \& Rupp D. E. (1999). “Are Procrastinators Prone to Boredom?”. Social Behavior and Personality: An International Journal 27/1 (1999) 11-16. Doi: 10.2224/sbp.1999.27.1.11

Vodanovich S. J., Verner K. M. \& Gilbride T. V. (1991). "Boredom Proneness: Its Relationship to Positive and Negative Affect". Psychological Reports 69 (1991) 1139-1146.

Vodanovich S. J. \& Watt J. D. (1999). "The Relationship Between Time Structure and Boredom Proneness: An Investigation Within Two Cultures". The Journal of Social Psychology 139/2 (1999) 143-152.

Watt J. D. \& Vodanovich S. J. (1999). "Boredom Proneness and Psychosocial Development". The Journal of Psychology 133/3 (1999) 303-314.

Wink P. \& Donahue K. (1997). “The Relation Between Two Types of Narcissism and Boredom”. Journal of Research in Personality 31 (1997) 136-140.

Zuckerman M. (1979). Sensation Seeking: Beyond the Optimal Level of Arousal. New Jersey 1979. 